\title{
REPRESENTAÇÕES EM RELATOS DE MEMÓRIA: O MISSIONÁRIO CATÓLICO QUINTO TONINI NO ANTIGO EXTREMO NORTE DE GOIÁS NA DÉCADA DE 1950
}

\author{
Raylinn Barros da Silva ${ }^{1}$
}

\begin{abstract}
Resumo: O objetivo deste estudo é analisar as representações de Quinto Tonini, missionário orionita italiano que viajou pelo antigo extremo norte de Goiás durante a década de 1950. Este estudo é resultado de uma pesquisa bibliográfica que considerou, como sua fonte principal, o livro Entre Diamantes e Cristais, de autoria do referido missionário. A hipótese é que Tonini empreendeu um esforço de memória para que ele próprio e seus missionários fossem lembrados como os desbravadores da região. A metodologia consistiu na análise da obra a partir de conceitos como "desobrigas", "sertão" e "sertanejos", interpretados a partir de estudos no campo da história cultural. A justificativa consiste na necessidade de historicizar essas memórias, o que contribui para a compreensão de parte da história religiosa da região.
\end{abstract}

Palavras-chave: Orionitas; Desobrigas; Sertão; Sertanejos; Goiás.

\section{REPRESENTATIONS IN MEMORY REPORTS: THE ORIONITE CATHOLIC MISSIONARY QUINTO TONINI IN THE OLD FAR NORTHERN OF GOIÁS IN THE 1950S.}

\begin{abstract}
The aim of this study is to analyze the representations of Quinto Tonini, an Italian Orionite missionary who traveled the ancient far northern of Goiás in the 1950s. This study is the result of a bibliographic search that considered, as its primary source, the book Between Diamonds and Crystals, authored by the referred missionary. The hypothesis is that Tonini undertook a memory effort so that he and his missionaries would be remembered as the pioneers of region. The methodology consisted in the analysis of Tonini's work from concepts such as "desobrigas" (name given to the travels that missionaries did to administer the sacraments), "outback" and "outback dwellers", interpreted from studies in the field of cultural history. The justification is the need to historicize these memories, which contributes to the understanding of part of the religious history of the region.
\end{abstract}

Keywords: Orionites; Desobrigas; Outback; Outback dwellers; Goiás.

\section{REPRESENTACIONES EN RELATOS DE MEMORIA: EL MISIONERO CATÓLICO ORIONITA QUINTO TONINI EN EL ANTIGUO EXTREMO NORTE DE GOIÁS EN LA DÉCADA DE 1950.}

Resumen: El objetivo de este estudio es analizar las representaciones de Quinto Tonini, misionero orionita italiano que viajó por el antiguo extremo norte de Goiás en la década de 1950. Este estudio es resultado de una investigación bibliográfica que consideró, como fuente

\footnotetext{
${ }^{1}$ Doutorando em História pela Universidade Federal de Goiás. E-mail: raylinn_barros@ @otmail.com.
} 
principal, el libro Entre Diamantes e Cristais, escrito por el referido misionero. La hipótesis es que Tonini emprendió un esfuerzo de memoria para que él mismo y sus misioneros fueran recordados como los exploradores de aquella región. La metodología consistió en el análisis de la obra a partir de conceptos como "desobrigas" (nombre dado a los viajes que los misioneros hicieron para ministrar los sacramentos), "campo" y "campesinos", interpretados a partir de estudios en el campo de la historia cultural. La justificativa se apoya en la necesidad de historicizar esas memorias, lo que contribuye para la comprensión de parte de la historia religiosa de la región.

Palabras clave: Orionitas; Desobrigas; Campo; Campesino; Goiás.

\section{Introdução}

A pesquisa bibliográfica que deu origem a este estudo ${ }^{2}$ partiu da análise da obra Entre Diamantes e Cristais: Cenas Vividas Pelos Missionários De Dom Orione Nas Matas Do Norte De Goiás, registro de memória do missionário orionita Quinto Tonini, religioso católico italiano que viajou e viveu na década de 1950, na região do antigo extremo norte de Goiás, atual norte do Tocantins ${ }^{3}$. Essa obra foi publicada no ano de 1996 e nela existem relatos únicos e considerados indispensáveis para a compreensão de parte da história religiosa católica da região. Ele registrou nessa obra as cenas que ele viu e o que viveu em suas viagens missionárias pela região.

A princípio, acredita-se que para entender o trabalho dos missionários católicos pelo interior do Brasil é preciso, primeiro, pensar o sentido que essas viagens possuem para esses religiosos. O sentido dessas viagens passa pela compreensão do que se convencionou chamar de "desobriga" ou, ainda, de "missão evangelizadora". Mas por que é necessária a compreensão dessa diferença entre ambas? Pelo motivo de que cada uma delas, a seu modo e a partir de seus métodos, se diferenciam nos objetivos a serem alcançados pelos missionários. É preciso, também, identificar em qual dessas duas práticas se enquadraram as viagens realizadas por Tonini no antigo extremo norte goiano, viagens registradas em suas memórias.

\footnotetext{
${ }^{2}$ Pesquisa desenvolvida com apoio do CNPq - Conselho Nacional de Desenvolvimento Científico e Tecnológico. ${ }^{3}$ Quinto Tonini pertenceu à 'Pequena Obra da Divina Providência', congregação católica fundada por Luís Orione, popularmente chamado de Dom Orione. Ele nasceu em Pontecurone, Itália, em 1872 e faleceu em Sanremo em 1940. Ao entrar para a vida religiosa, pertenceu à congregação dos padres salesianos, ordem religiosa fundada pelo sacerdote Dom Bosco, de quem Dom Orione desfrutou de amizade. Em 1903, na cidade de Tortona, Itália, sua congregação recebeu aprovação canônica por parte da Igreja. Essa congregação é formada por padres, freiras e leigos consagrados. A partir da metade do século XX, os orionitas se espalharam pelo mundo, inclusive pelo Brasil, são chamados 'Filhos da Divina Providência'. Dom Orione Foi beatificado em 1980 e canonizado em 2004, as duas cerimônias foram presididas pelo então papa João Paulo II. Para mais informações sobre a vida e obra de Dom Orione, consultar: PATTARELLO, Giovani. Perfil de Dom Orione. São Paulo: S/Editora, 1985.
} 

na década de 1950 - Raylinn Barros da Silva

Nesse sentido, Edivaldo Antônio dos Santos, que estudou a ação dos missionários dominicanos na região central do Brasil na passagem do século XIX para o XX, quando busca explicar a diferença entre missão evangelizadora e desobriga, reflete:

O missionário ia, a convite do pároco local, para reavivar o fervor do povo, através da evangelização, que durava dias seguidos. $O$ povo se reunia normalmente na Igreja Matriz do lugar para ouvir os religiosos e se confessar. As igrejas lotavam e havia grande interesse por parte da população. Após a pregação, seguia-se a recitação do rosário. As missões evangelizadoras enfatizavam a conversão pessoal e a intensificação da vida cristã (SANTOS, 1996, p.98).

Como é possível perceber na análise de Santos, o sentido ou o principal objeto da missão evangelizadora consistia no que ele chama de "conversão" e "intensificação da vida cristã”. Ou seja, essas missões objetivavam, primeiro, converter as populações interioranas e, a partir daí, introduzi-las na vida cristã católica. Era uma espécie de conquistar e manter a conquista. Segundo ele, o missionário ia à localidade a convite do pároco local e, a partir daí, trabalhavam numa parceria que durava alguns dias.

Já no que se refere às chamadas desobrigas, o sentido e o objetivo eram outros, pois, segundo Santos:

\begin{abstract}
Nas desobrigas o trabalho missionário consistia sobretudo na administração dos sacramentos. Durante esse trabalho, os missionários saíam geralmente no lombo de burros, em direção a diversos lugarejos. E chegando, reuniam a população de toda redondeza para cumprir as obrigações religiosas: a comunhão e a confissão anual, crisma, casamentos, regularização das uniões de fato. Quando necessário, levavam também a Unção dos Enfermos. A passagem do sacerdote missionário era muito esperada pelo povo, pois a passagem do missionário era uma oportunidade de ficar em paz com as obrigações religiosas, visto que, em muitos casos, teriam outra oportunidade somente vários anos depois (SANTOS, 1996, p.98-99).
\end{abstract}

A partir das reflexões de Santos, pode-se inferir que as missões evangelizadoras tinham o caráter de conquista de fiéis e de manutenção e aprofundamento da fé dos mesmos, ao passo que as desobrigas tinham o caráter exclusivo de administração dos sacramentos. Nesse sentido, durante o projeto de expansão religiosa do catolicismo missionário pelo interior do Brasil, primeiro haveria de acontecer a chamada missão evangelizadora, para se concretizar a conquista de fiéis e, na sequência, a desobriga para a manutenção dos sacramentos.

A partir dessa diferenciação, cabe uma indagação: em qual dessas duas práticas se deu a ação de Tonini pelo sertão do antigo extremo norte goiano na década de 1950? A partir das 
reflexões de Santos, pode-se localizar a ação do missionário orionita dentro do que se entende por desobriga. Por dois motivos: primeiro como será possível observar neste estudo, Tonini, em suas memórias, expressa claramente a prática da administração dos sacramentos como principal trabalho desenvolvido. Segundo, como a missão evangelizadora atendia sempre à convocação do padre local, Tonini não contava com esse chamado de padres locais, pois eles não existiam no antigo extremo norte goiano na década de 1950.

Na região, com exceção de Tocantinópolis, que era a única paróquia que havia na época, não existiam outras paróquias, nem padres. Tonini e os orionitas foram, portanto, a partir de 1952, os únicos a realizarem as viagens missionárias pela região. Mas como Tonini representou em suas memórias essas viagens missionárias?

\section{As viagens missionárias de Quinto Tonini pelo Antigo Extremo Norte Goiano}

O extremo norte goiano, objeto de reflexão neste estudo é a região onde, na atualidade, denomina-se como norte tocantinense. Os missionários orionitas estabeleceram-se na região no ano de 1952 e, como resultado de ações no campo da fé - como construção de igrejas, fundação de postos de saúde, hospitais e também escolas -, terminaram por estruturar o catolicismo na região. Um dos principais missionários desse grupo foi Quinto Tonini, suas memórias são objeto de reflexão neste estudo.

Nesse sentido, identificado o trabalho dos missionários orionitas no que se entende por desobriga, resta entendermos como funcionou as viagens de Tonini pela região objeto deste estudo. A desobriga foi, portanto, uma viagem realizada por um ou mais religiosos com o objetivo de visitar regiões mais longínquas da sede da paróquia. Para Tonini:

A desobriga é uma viagem missionária que o sacerdote faz uma ou mais vezes ao ano, no interior de sua paróquia, para dar ao povo pobre e que habita muito distante da igreja a possibilidade de receber os sacramentos (TONINI, 1996, p.32).

Para Tonini, as viagens missionárias tinham como objetivo assistir aos fiéis das regiões mais distantes e que pouco conviviam cotidianamente com os religiosos. A distância entre os sertões e suas paróquias obrigou os orionitas a promoverem essas viagens de forma que, além da administração dos sacramentos, eles pudessem, de tempos em tempos, manter um contato mais próximo com os fiéis da região. 


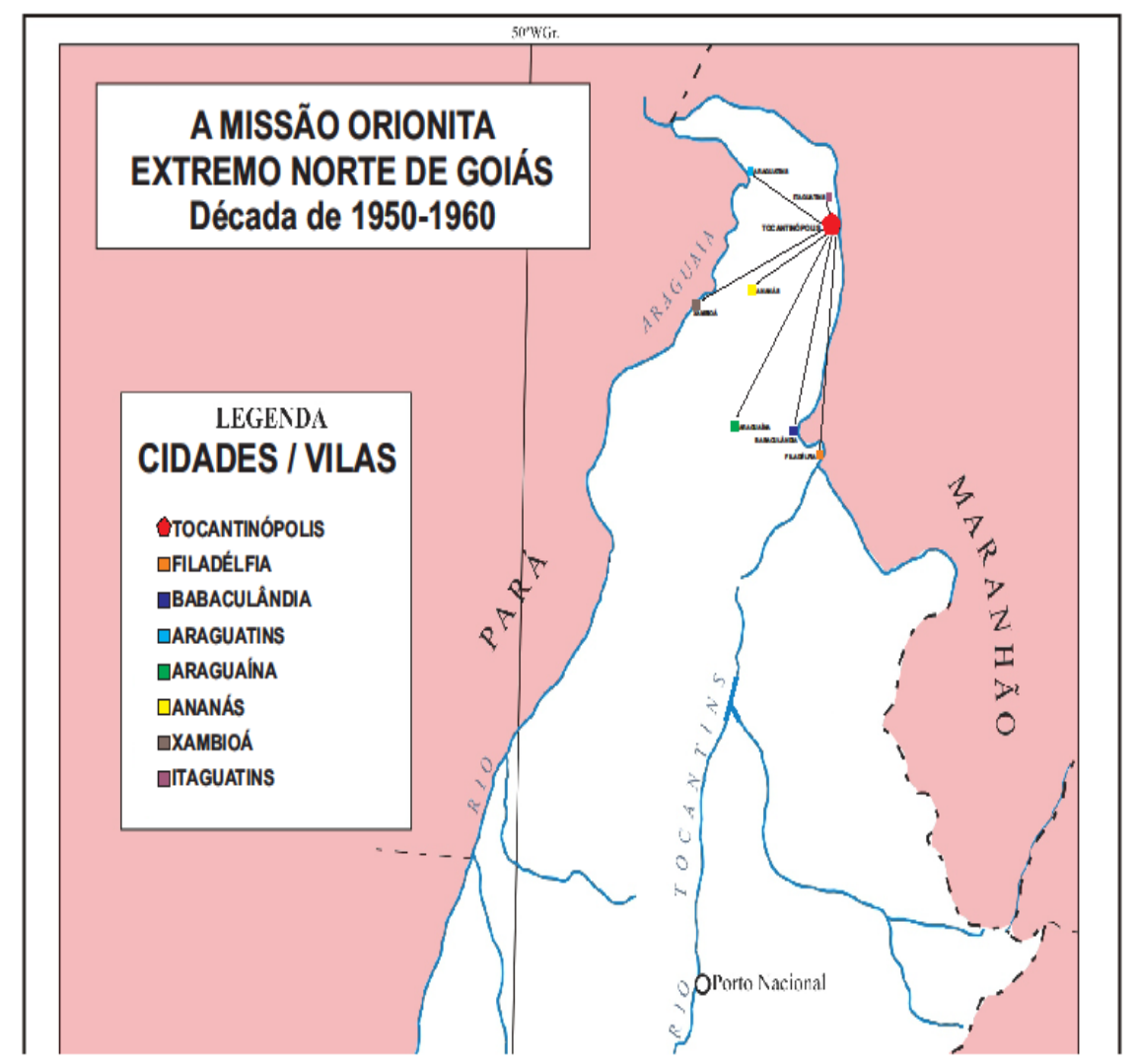

Fonte: Imagem produzida a partir da leitura das fontes autobiográficas dos orionitas.

Vale observar, a partir da memória de Tonini, que, para o missionário, o principal objetivo da viagem era mesmo a administração dos sacramentos religiosos. Na representação do missionário e da igreja, essas viagens possuíam um caráter religioso. Mas pode-se inferir que essas viagens tinham um caráter para além de religioso. Essas viagens e o resultado delas, ou seja, os sermões - pregações de caráter religioso feito pelo sacerdote -, traziam consigo uma natureza também moral e ética.

Sobre esse outro caráter da desobriga, a da busca pelo estabelecimento de uma unidade moral, religiosa e ética entre os povos alcançados por essas práticas religiosas, Peri Mesquita, quando reflete sobre as desobrigas, infere:

Desde que haja um mínimo de articulação entre os agentes religiosos do catolicismo popular (povo) e os agentes do catolicismo oficial (missionários), por meio das visitas de desobriga, das missões populares, da presença dos padres nos santuários esporadicamente, pelas capelanias, etc. a unidade religiosa, moral e ética do povo estava assegurada (MESQUITA, 2000, p.7). 
Ainda sobre esse outro caráter das desobrigas, ou seja, o interesse por parte dos missionários no estabelecimento de uma unidade não só religiosa, mas também moral e ética; Rodrigo de Souza Ferreira, quando reflete sobre as missões religiosas pelo interior do Brasil, infere:

Mesmo sendo pouco numerosos, os padres dessas desobrigas cumpriram a função de manter a unidade religiosa, moral e ética do todo. Através de visitas esporádicas, sobretudo por ocasião de missões populares e da realização da desobriga, esses padres asseguravam a manutenção do culto católico pelo interior do país. (FERREIRA, 2005, p.101).

Acredita-se que esse aspecto moral e ético que consideramos indissociável do discurso religioso tem como objetivo final o que podemos chamar de "direcionamento" das consciências dos fiéis. De qualquer forma, e como será possível observar neste estudo, no contexto histórico do antigo extremo norte goiano, as viagens missionárias dos orionitas traziam consigo muito mais que um objetivo religioso. Já no que se refere à "logística" das viagens, Tonini registrou:

Geralmente paramos de 20 em $20 \mathrm{~km}$ em choupanas e junto à família que acredita ser mais conveniente. O chefe da família, avisado ao menos um mês antes, reavisa por sua vez, todos os habitantes da redondeza. Pode acontecer de alguma família não ser avisada e por isso, julgar-se 'non grata' ao dono da casa e não ir à missa (TONINI, 1996, p.32).

Observam-se dois momentos importantes das viagens. O primeiro se refere ao momento em que Tonini cita o fato de que as paradas são realizadas em casas de famílias que o sacerdote julga serem mais convenientes. Essa parte da memória do missionário leva a acreditar que as viagens missionárias e suas paradas não eram feitas de forma aleatória, sem um planejamento mínimo prévio. Quando ele registrou que deveriam se hospedar em casa de família mais conveniente, fica claro que há uma seleção das famílias que iriam os receber, possivelmente uma seleção das famílias que eles julgavam estarem mais preparadas do ponto de vista moral.

Outro ponto interessante a ser destacado diz respeito ao fato de alguma família da região visitada pela desobriga não ser avisada e por esse motivo ficar de fora dos trabalhos religiosos a serem administrados pelos missionários. Essas famílias que poderiam ser "contempladas" pelo possível infortúnio, além de serem excluídas dos sacramentos dispensados pelos missionários, deixavam ainda de se socializarem com os seus "conterrâneos". 
Pode-se, a partir do registro de Tonini, inferir que podem ter sido comuns essas situações de exclusão de famílias durante as desobrigas pela região. O que pode levar a acreditar que o ambiente social de convivência em algumas regiões do antigo extremo norte goiano não era sempre de harmonia e solidariedade mútua. Essa "animosidade" social não parece ter sido alvo de atenção por parte dos missionários.

Para as populações distantes das paróquias e que recebiam, esporadicamente, as desobrigas, as mesmas pareciam ser um momento de festa e celebração, do qual todos da família precisariam participar. Era o momento em que as pessoas se "ajustavam" com Deus, como pode-se perceber quando Tonini registrou:

Os convidados chegam ao declinar do sol, a pé ou a cavalo, levando crianças para batizar, jovens para crismar, rapazes e moças para casar, quadros e imagens, velas e fósforos para benzer. Às vezes, por delicadeza com os donos da casa que os convidaram, fazem de 30 ou 40 quilômetros de estrada. Outras vezes vão a dois ou mais lugares, seja porque lhes convém, ou mesmo para satisfazer ao convite (TONINI, 1996, p.32).

Além da administração dos sacramentos religiosos, como o batismo, a crisma e o casamento; era costume levar para as desobrigas objetos de uso cotidiano que eram utilizados nos afazeres domésticos e no trabalho, como quadros, imagens, velas e fósforos. Vale ressaltar que é costume antigo entre os fiéis da igreja a chamada "benzeção" religiosa de artefatos para o uso pessoal e doméstico, essa prática inclusive é comum até hoje em muitos templos católicos.

Outro ponto a ser refletido no último registro de memória de Tonini diz respeito à parte final, quando ele registrou que algumas pessoas iam às desobrigas simplesmente para satisfazer o convite do dono da casa que ia receber o missionário. É interessante pensar, a partir desse detalhe, que a participação nas celebrações religiosas das desobrigas orionitas não ocorria exclusivamente por um sentimento de fidelidade aos missionários nem à igreja, ou à própria desobriga; mas, em alguns casos, era uma presença "protocolar", em respeito ao dono da casa que recebia as celebrações, uma cordialidade, um agradecimento pelo convite.

Em outro momento das memórias de Tonini, observa-se a importância dada à alimentação dos participantes da desobriga, tanto a dos missionários como a dos fiéis. Segundo Tonini:

O proprietário da fazenda, se tem possibilidade, abate um bovino, ovino ou suíno. Se pobre, aves do próprio quintal e dá comida a todos os convidados. Caso contrário, limita-se ao café com bolo, uma espécie de biscoito de polvilho, na chegada e na saída. Durante a noite, todos dormem na mesma choupana: homens, mulheres, crianças, cães, cabritos e algum porquinho. 
Aqueles que não cabem na cabana, prendem as suas redes sob as plantas, que são abundantes (TONINI, 1996, p.32-33).

Pode-se inferir que essa "logística" da alimentação dos participantes das viagens missionárias pode ser considerada a mais "democrática" possível, pelo fato de oferecer possibilidade para que todos pudessem receber a desobriga em sua casa, em sua fazenda. Notase, pela descrição de Tonini, que na escolha prévia do lugar para a alimentação parecia não ser dada prioridade a quem tem mais condição financeira e possibilidade de melhor servir os participantes. Nesse sentido, ao que parece, todos poderiam contribuir nas recepções das viagens missionárias, as chamadas desobrigas.

Outro ponto a se observar refere-se ao fato da acomodação dos participantes logo após a alimentação com vistas às celebrações do dia seguinte. Tonini registrou que todos dormiam nas mesmas instalações, desde os adultos até as crianças e, o curioso, também alguns animais. Esse registro do missionário, ao escrever que nas instalações dormiam pessoas e também animais, parece ressaltar o caráter de pobreza e humildade das viagens missionárias. Esse tipo de acontecimento lembra uma passagem pode ser encontrada nos evangelhos quando, ao se aproximar do nascimento de Jesus, sua família teria se hospedado em instalações humildes, junto com animais. Mas as dificuldades apareceram em alguns momentos das desobrigas, conforme ele registrou:

As viagens ocorriam sempre de uma às seis da tarde, sob a ira selvagem do sol equatorial. A primeira parte da noite era toda para a função religiosa e as confissões. A manhã era cheia, entre a santa missa e a administração dos sacramentos. A vida não era de forma nenhuma confortável (TONINI, 1996, pp.37-38).

As viagens sempre ocorriam na parte da tarde. A noite e as manhãs eram reservadas aos ofícios religiosos. Isso faz acreditar que havia uma racionalidade expressa em todo o processo que envolvia as desobrigas, desde a preparação das rotas, passando pela viagem em si, sempre no lombo dos animais, a alimentação, até a escolha dos horários, de forma a permitir agilidade e maior produtividade aos eventos.

Os missionários pareciam amenizar seus cansaços ao observarem "bem encaminhada" a missão. De fato, junto ao cansaço, ao que parece, existiam momentos de felicidade quando da realização das desobrigas. Sobre o misto de sofrimento e cansaço com alegria e felicidade das viagens missionárias, Tonini registrou: 

na década de 1950 - Raylinn Barros da Silva

Não restava dúvida de que era um trabalho árduo e penoso que muitas vezes desencadeava um cansaço fatigante. Mas esse último era consolado pela satisfação em ver tudo sendo encaminhado, o trabalho sendo realizado e a fé sendo nutrida entre aquele povo que esperava quase tudo de nós, do consolo à força para continuar a vida (TONINI, 1996, p.118).

Sobre a convivência entre sofrimento e alegria no interior das desobrigas e do trabalho missionário, acredita-se que os sofrimentos que estavam submetidos os missionários eram de escolha consciente dos mesmos. Pelo exposto no registro de memória de Tonini, é possível perceber que os missionários em suas viagens se sentiam felizes e realizados pela escolha que fizeram, pelo seu estilo de vida e pela missão que colocaram como sentido para as suas vidas.

Sobre o sofrimento muitas vezes vivenciado pelos missionários em suas desobrigas e a relação desses sofrimentos com a felicidade de cumprirem seus destinos de vida, Edivaldo Antônio dos Santos reflete:

Diante dessas e de outras dificuldades surge uma pergunta: onde o missionário encontra forças para continuar a labuta? Onde encontra forças para não desanimar diante de tão árdua missão? Que força misteriosa move o missionário por esse sertão brasileiro? Ainda mais: sabendo-se que o missionário era um homem feliz, pergunta-se como é possível equacionar sofrimento e alegria sem cair no ridículo do masoquismo? De fato ele sabe equacionar estas duas realidades que em si são excludentes: sofrimento e alegria (SANTOS, 1996, p.40).

A partir da reflexão de Santos, fica evidente a relação entre sofrimento e alegria no interior das desobrigas. Mas resta uma questão: como entender a coexistência dessas duas dimensões do cotidiano humano, sem olhar para essa oposição como algo inconciliável? Como podemos entender essa vivência missionária de sofrimento e ao mesmo tempo de felicidade?

Para a compreensão dessa relação sofrimento/alegria na vida missionária, Santos ainda infere:

O mundo materialista em que vivi e o homem moderno não conseguem captar esta realidade. Isto é masoquismo, diz-se a partir de uma ótica puramente humana e materialista. A partir desta ótica, não é possível entender a ação missionária. Para entendê-la é necessário mergulhar nesse universo místico e misterioso da genuína espiritualidade cristã onde a alegria de saber-se trabalhando para Deus, dá forças para suportar toda espécie de adversidades. Então será possível compreender como o missionário é tão feliz no meio de tantas fadigas (SANTOS, 1996, pp.40-41). 
Nesse sentido, de acordo com Santos, a compreensão do trabalho missionário só é possível quando ele é observado pela ótica do prazer em "trabalhar" para Deus. Assim, segundo Santos, fora dessa ótica, que acima de tudo é espiritual, o serviço missionário torna-se incompreensível.

Acredita-se que, anos depois do início da missão, os orionitas começaram a adquirir experiência em suas viagens pelo extremo norte goiano. De fato, o valor residente na vida de um religioso em missão devia ter sua importância. Entende-se que as experiências adquiridas ao longo dos primeiros anos das missões no antigo extremo norte goiano fizeram com que eles passassem a atribuir a si uma representação certamente diferente da que tinham produzido de si mesmos antes de iniciarem a "aventura" que foi fazer parte do cotidiano da região norte goiana na metade do século XX.

Portanto, a partir do conceito de representação, como Tonini representou as viagens missionárias em sua memória escrita? Como foi possível perceber, o missionário orionita representou em suas narrativas as viagens como difíceis e penosas, sobretudo devido às distâncias que precisaram ser percorridas. Mas foram viagens também planejadas do ponto de vista dos ofícios religiosos, eles dividiram o tempo de acordo com as necessidades de cada região a ser visitada. Vale observar que os missionários receberam considerável apoio nas viagens, sobretudo no âmbito da alimentação e da hospedagem.

Portanto, ao que parece, foram viagens difíceis, mas que eles se sentiram satisfeitos ao término delas. É o que se pode deduzir dos registros de memória do missionário Tonini sobre as viagens. Para entendermos melhor essas representações construídas pelo missionário, Roger Chartier reflete:

\begin{abstract}
A história cultural, tal como a entendemos, tem por principal objeto identificar o modo como em diferentes lugares e momentos uma determinada realidade social é construída, pensada, dada a ler. Uma tarefa deste tipo supõe vários caminhos. O primeiro diz respeito às classificações, divisões e delimitações que organizam a apreensão do mundo social como categorias fundamentais de percepção e de apreciação do real (CHARTIER, 1982, p.17).
\end{abstract}

A partir de Chartier, pode-se inferir que as viagens missionárias dos orionitas representadas nos registros de memória de Tonini significaram a realidade do trabalho missionário, mas sobre aquela realidade o orionita construiu sua própria representação; como foi possível perceber, ele pensou sobre as viagens e, a partir daí, deu a elas a sua própria leitura, ou seja, deu àquelas viagens a sua representação, seu registro de acordo com suas percepções. 
Para além das viagens missionárias dos orionitas, chamadas de desobrigas, representadas nas memórias de Tonini, em qual lugar essas desobrigas ocorreram? Como ele registrou o lugar em suas memórias? A seguir, trataremos sobre o sertão do antigo extremo norte goiano e como ele foi representado nas memórias de Tonini.

\section{O sertão do Extremo Norte Goiano nas representações de Quinto Tonini}

As viagens missionárias, também chamadas de desobrigas, realizadas pelos missionários orionitas se deram no antigo extremo norte goiano, lugar denominado por eles próprios de sertão. Nesse sentido, para refletirmos sobre esse espaço social, o sertão do extremo norte goiano na década de 1950, faz-se necessário uma breve compreensão do conceito de sertão.

A historiografia aborda essa problemática e considera-se que, para a compreensão do sertão do extremo norte goiano na década de 1950, espaço social de atuação dos missionários orionitas, não poderíamos deixar de dialogar, ainda que de forma breve, com essa problemática neste estudo. Sobre o conceito de sertão, Janaína Amado infere:

Sertão é, também, uma referência institucionalizada sobre o espaço no Brasil. Convertendo-se, assim, em uma categoria espacial, uma categoria de pensamento social, uma categoria cultural e, por fim, uma categoria construída durante a colonização (AMADO, 1995, p.145).

A partir de Janaína Amado, observa-se a importância das discussões quanto à noção de sertão e seu uso na pesquisa historiográfica. Mas em linhas gerais, por que a necessidade de problematização do conceito de sertão? O geógrafo Aziz Nacib Ab’Saber (1985), em suas reflexões sobre os sertões e a construção do que ele nomeou de "originalidade da terra", chamou a atenção para a necessidade de sempre especificar a qual sertão estamos nos referindo.

A chamada perspectiva "euclidiana" se tornou clássica por, entre outras coisas, associar a ideia de sertão à de paisagem e, consequentemente, à paisagem do nordeste brasileiro, especialmente do semiárido nordestino, lugar de seca e de pobreza. Nascia a chamada matriz geográfica para a análise da ideia de sertão, o meio geográfico como elemento determinante do que viria a ser compreendido como sertão.

Mas não só essa perspectiva "euclidiana" conviveu nas análises que se seguiram às discussões sobre a noção de sertão. Existe ainda a perspectiva que podemos chamar de romântica e que, entre outras coisas, viu no sertão um espaço, uma espécie de último refúgio 
do homem que, ainda não "contaminado" pelo poder avassalador e destruidor do "progresso" e da "civilização", ali residiria. E por fim, há também a perspectiva inferiorizante de sertão que, visto como portador de realidade diferente daquelas do litoral, seria, com relação a este último, inferior, menor, por ser diferente.

Nesse sentido, no caminho para se estabelecer um olhar que não ficasse demasiadamente preso a essas perspectivas acima expostas, e tendo em vista a necessidade de refletirmos no sentido de estabelecermos uma leitura mais atual e clara quanto à ideia de sertão e a aproximação deste com o espaço social que o missionário Tonini encontrou a partir na década de 1950 em Goiás, considera-se mais oportuno olhar o sertão do extremo norte goiano a partir de um novo olhar, como reflete Olívia Cormineiro:

Compreendemos o sertão como um espaço delimitado e diverso que, apesar das dificuldades em apreendê-lo, pode ser caracterizado por sua relacionalidade. Desta forma, se o sertão se definia, em uma perspectiva clássica, por sua oposição ao litoral, compreendemos que ele se define em relação ao seu outro, seja o litoral, o progresso ou o "civilizado". O avanço aqui é que não mais prevalece uma ideia de inferioridade, mas de tensão entre diferentes e desiguais (CORMINEIRO, 2010, p.21).

Nesse sentido, para uma nova interpretação quanto à ideia de sertão, acredita-se que ele está, de fato, muito além de uma visão que o inferioriza, bem como da perspectiva clássica de Euclides da Cunha, por seu apego à paisagem, ao semiárido e ao espaço geográfico nordestino; como também está muito além de um espaço de refúgio do homem não atingido pelo "progresso" destruidor. Assim, seguindo a leitura de Cormineiro, é possível enxergar no sertão do extremo norte goiano na década de 1950 um espaço de relação entre diferentes, no caso em tela, de um lado os sertanejos, de outro lado os missionários orionitas, entre eles, Tonini.

Mas por que espaço de relação entre diferentes? Possivelmente porque eram sujeitos completamente diferentes, e não só porque os orionitas eram religiosos e não pessoas comuns; também porque, diferentemente das pessoas da região, eram portadores de uma cultura europeia, considerada "culta", mas que ali estavam para estabelecer um projeto religioso que tinha como alvo o outro, o sertanejo, também portador de uma cultura própria. É nessa relação entre sertanejos e missionários orionitas, que por vezes resultou em tensão, que se construiu uma vivência marcada, entre outras coisas, pelo que Olívia Cormineiro denominou de "tensão entre diferentes e desiguais". 
Sobre o sertão encontrado pelos missionários na década de 1950, o extremo norte goiano, pela ordem de importância, primeiro considera-se Tocantinópolis, por ter sido a sede da única paróquia e maior cidade da região no contexto. Filadélfia tinha destaque por fazer divisa com a cidade de Carolina no Maranhão e por ser considerada estratégica pelos próprios orionitas, devido à existência de uma igreja protestante já consolidada, pertencente aos batistas, além de uma associação maçônica.

Na sequência, acredita-se que Babaçulândia, depois Araguaína, Araguatins e, por último, a cidade de Itaguatins. Não coincidentemente, a maioria desses centros urbanos do antigo extremo norte goiano era margeado por rios de grande porte. Com exceção de Araguaína, que, ao que parece, foi incluída nesse grupo por de ter um rebanho católico reconhecidamente fiel à igreja, condição que agradou os missionários.

Com relação à sede da missão, Tocantinópolis, que também tinha a única paróquia de todo o sertão do antigo extremo norte goiano, as representações de Tonini associaram essa cidade à pobreza; além disso, o missionário a considerava como lugar de "desvios" morais e religiosos, pois, segundo Tonini:

O panorama era nada acolhedor. E ainda à entrada, nas cabanas, constatavase a miséria por toda parte. A narração dos sofrimentos físicos e morais dos adultos, gelavam, com certeza, o coração. Logo de início, tivemos a impressão da própria fraqueza e insuficiência, diante de tanta necessidade (TONINI, 1996, p.11).

Como observado, os registros de memória de Tonini marcaram Tocantinópolis como uma região associada à pobreza e à miséria. Ao registrar sofrimentos físicos, doenças e também sofrimentos morais dos sertanejos pobres da região de Tocantinópolis, o missionário observou que toda a situação de miséria vivida pelo povo pobre da região não estava apenas ligada aos problemas de saúde.

Sobre Filadélfia, foi representada nas memórias de Tonini como a mais estratégica para a missão orionita. Isso porque, além de fazer fronteira geográfica com Carolina, importante centro urbano do estado do Maranhão na época, a cidade já contava com igrejas protestantes e, para aumentar a preocupação dos missionários orionitas, ainda era sede de uma loja maçônica, única na região.

Nesse sentido, Filadélfia era um terreno que deveria ser muito bem cuidado pelos missionários, conforme se observa quando Tonini registrou: 
Filadélfia, por situar-se diante de Carolina, centro avançado de todas as associações e seitas inimigas da Igreja, deveria ser uma pequena fortaleza católica para canalizar os ataques frontais contra aqueles pobres trabalhadores, ainda desesperados na defesa dos seus princípios religiosos (TONINI, 1996, p.174).

Filadélfia, como uma das "portas" de entrada para o extremo norte goiano pelo rio Tocantins por quem vinha do Maranhão, contava com a presença da religião protestante. Para os missionários orionitas, essa preocupação consistiu num dos principais desafios para a missão em solo goiano. Não coincidentemente, Tonini registrou em suas memórias a necessidade de "ataques frontais" contra os protestantes que, para os orionitas, eram considerados os “inimigos" do catolicismo no contexto da região.

Babaçulândia, assim como Filadélfia, era também localizada às margens do Rio Tocantins. Sobre Babaçulândia, assim registrou Tonini:

Fora formada pouco a pouco, desde 1925 em diante. A zona é riquíssima em coco babaçu, utilizado no fabrico de óleo, bom para o preparo de alimentos, para fazer sabões e perfumes. É o município mais rico de serras, no meio das quais se estendem imensos vales, cobertos de florestas, que vistas do alto parecem tapetes cor de esmeralda (TONINI, 1996, p.41).

A região de Babaçulândia era rica em recursos naturais que permitiam a extração para a produção de bens como sabão e essências. Até hoje essa região é rica em coco babaçu, importante meio de vida para as pessoas que ainda vivem da extração dessa riqueza natural. Babaçulândia foi uma das mais antigas e conhecidas cidades do extremo norte goiano. Lá também se estabeleceram os missionários orionitas. Ao chegar lá, registrou o missionário:

Era a primeira vez que o Padre Tonini entrava naquela vila. A gente, das janelas e das portas, observava atônita. Chegados à casa de Henrique Brito, habituado a hospedar os padres, apareceu uma velhota limpa, ligeira, discreta, piedosa e inteligente. O bispo disse ao missionário: "aquela velha é uma bela alma. Não tem cultura, porém foi ela quem sustentou a fé, por vinte anos, nesta vila, desprovida de sacerdote. É a zeladora da capela e chama-se Alexandrina Costa" (TONINI, 1996, p.41).

Babaçulândia, ao "receber" os missionários, assim como outros centros urbanos da região, buscou em algumas figuras locais prover esses religiosos de assistência: pessoas os ajudaram. Muito comum, ao que parece, foram recepções admiradas e curiosas por parte dos sertanejos com relação aos orionitas. Segundo Tonini, o sertanejo, ao mesmo tempo em que 
reagia com curiosidade e admiração à chegada dos religiosos, também se se mostrava disposto a servir.

Araguaína foi um povoado importante para os orionitas, o único não margeado pelos dois principais e maiores rios da região, o Tocantins e o Araguaia. Mas ainda assim, Araguaína era margeada por outro rio: Lontra, importante afluente do Araguaia e que a este dava acesso. Sobre Araguaína, Tonini registrou:

\begin{abstract}
Araguaína é uma cidadezinha exclusivamente agrícola, formada pouco a pouco às margens do Rio Lontra, com a chegada dos retirantes perseguidos pela seca do nordeste brasileiro. No dia 17 de junho lá chegamos para a festa do Sagrado Coração de Jesus, padroeiro do lugar. A novena foi muito animada. A capela de palha não comportava sequer um décimo dos fiéis presentes. As paredes foram abertas de modo que de fora se assistissem às funções como se estivessem dentro (TONINI, 1996, p.29).
\end{abstract}

Ao que parece, Tonini deixou claro o sucesso de suas "empreitadas" pelo povoado de Araguaína. Desde as recepções nas casas das pessoas que os acolhiam, o fervor das celebrações, até a fé dos habitantes do lugar. Mas por que nos registros de memória de Tonini o religioso narrou Araguaína como um lugar especial? O que houve de tão interessante que valorizou Araguaína e a colocou em condição especial aos olhos dos missionários?

Filadélfia, como se observou, foi também importante, porque do ponto de vista estratégico estava localizada de frente para Carolina no Maranhão, berço do protestantismo na região e sede da maçonaria. Babaçulândia também tinha sua importância, por estar localizada às margens do Rio Tocantins e ser ponto de acesso para Araguaína. E esta última, ao que parece, foi registrada nas memórias de Tonini com especial atenção

Então por que nos registros de memória de Tonini a cidade sede da missão e da paróquia - Tocantinópolis - se destacou de forma negativa? Será pelo fato de a tragédia que marcou o início da missão orionita no ano de 1952, o naufrágio que ceifou a vida de alguns dos primeiros missionários, ter ocorrido em Tocantinópolis? Essa é apenas uma hipótese e sobre a qual não se tem ainda uma resposta.

Vale observar que além de Tocantinópolis, Filadélfia, Babaçulândia e Araguaína, outras cidades e povoados "receberam" os orionitas na década de 1950, como Araguatins e Itaguatins e, na década seguinte, Nazaré, Ananás e Xambioá. Portanto, como Tonini representou em suas memórias o sertão do antigo extremo norte goiano?

Primeiro, vale observar que Tonini representou o lugar chamando-o de sertão. A representação que ficou registrada em suas memórias sobre o sertão do extremo norte goiano 
na época foi, então, de lugar marcado pelo abandono, pobreza, dificuldades de toda ordem e de esquecimento; mas também, por outro lado, um campo aberto para o trabalho missionário deles.

Assim como Roger Chartier, acredita-se que os estudos sobre as representações ajudam a entender processos de produção de sentidos. Infere-se que Tonini, como missionário que foi no sertão do antigo extremo norte goiano, buscou também produzir um sentido para o sertão que ele conheceu e viveu. Segundo Chartier, "os esquemas intelectuais, que criam as figuras graças às quais o presente pode adquirir sentido, o outro tornar-se inteligível e o espaço ser decifrado" (CHARTIER, 1982, p.17).

Nesse sentido, entende-se a partir de Chartier esse processo de produção de sentidos, no caso, as representações construídas pelo missionário Tonini sobre o espaço social do extremo norte de Goiás na época: o sertão; consequentemente, acredita-se, este tornou-se um pouco mais “inteligível” e "decifrado", para utilizar os termos do próprio Chartier. Nesse sertão que Tonini conheceu e registrou, quem nele habitava e com quem ele conviveu no transcurso das suas viagens missionárias, as desobrigas?

Os sertanejos do antigo extremo norte goiano e como eles foram representados nas memórias de Tonini são objetos de reflexão a seguir.

\section{Os sertanejos do Antigo Extremo Norte Goiano nas representações de Tonini}

Esta última parte deste estudo é dedicada à compreensão das representações que foram registradas nas memórias de Tonini sobre os sertanejos do extremo norte goiano na década de 1950. Acredita-se que para entendermos um pouco sobre o universo do sertanejo. como também o próprio uso desse conceito, seja necessário estabelecermos um breve diálogo com as discussões que abordam os significados do conceito de sertanejo.

Fadel David Antônio Filho, quando reflete sobre o significado e uso do conceito sertanejo, esclarece que 'É comum no Brasil denominar o homem do interior de 'sertanejo', caracterizado como uma pessoa simplória e possuidora de uma cultura peculiar" (FILHO, 2011, p.86). A partir de Filho, entende-se que o conceito de sertanejo se refere, essencialmente, às populações que habitam as regiões interioranas do Brasil.

Mas afinal de contas, quem eram essas pessoas que Tonini e os missionários orionitas encontraram no início das missões, no advento da década de 1950, no antigo extremo norte goiano? A partir da necessidade de compreender esses sertanejos, buscamos com cuidado nos atentar para não estabelecermos tipologias de forma rígida, que não é o objetivo deste estudo. 
Nesse sentido, entendemos como "sertanejo" essencialmente o habitante do extremo norte goiano na época: homens, mulheres e crianças, na maioria das vezes pobres e, como tais, possuidores de uma cultura comum; ou seja, viviam com pouco em seu cotidiano. Assim, considera-se o sertanejo da região, na época, como pessoas comuns.

Os sertanejos "receberam" os orionitas e os aconselhavam, os hospedavam e serviamlhes cotidianamente. Essa relação, na maioria absoluta das vezes amistosa, pode com toda certeza ter favorecido o trabalho dos missionários. Insiste-se nessa leitura, pois se considera que a relação entre os sertanejos e Tonini e os missionários não parece ter se dado de forma hostil, pelo contrário, eles serviram os missionários, conforme pode-se observar neste registro de memória de Tonini, quando escreveu:

O velhinho que dava as boas-vindas ao padre era um sertanejo camponês muito educado e gentil. Sabia ler e escrever, tinha pelo sacerdote o mesmo respeito que tinha por Jesus. A consorte, a sua velhinha era morena, magra como um espeto e também gentil. Enchiam-se eles de delicadeza para com o missionário. Aquele sertanejo acompanhou o padre ao banho. Passando sob o laranjal disse: "Eis, padre, estas duas laranjeiras foram reservadas para o senhor. Sei que gosta muito de laranjas. Não deixei que ninguém tirasse laranjas nestas duas árvores". Responde o Padre: "Não bastava uma?" O sertanejo explicou depois: "É porque são de sabores diferentes. Daí o senhor escolherá a que quiser" (TONINI, 1996, p.61-62).

Como se verifica no registro de Tonini, o sertanejo apresentou uma clara disposição em servir o missionário. No diálogo, observa-se que foi uma relação de respeito e afetividade. Na maioria das vezes, ao que parece, Tonini e os missionários receberam apoio e acolhida dos sertanejos da região.

Mas os sertanejos tinham, também, em suas relações com os orionitas, autonomia de decisão. Ou seja, eles agiram respeitando o que eles acreditaram ser melhor para eles e para o sertão que viviam, conforme se pode observar no diálogo entre uma sertaneja e Tonini:

Na hora da despedida perguntou, brincando, à senhora: "O que posso dar-lhe em recompensa por tantos sacrifícios realizados para nós nestes dias?" A mulata não se alterou. Passou os olhos para o Sacerdote, que estava atrás, depois olhou novamente para o interlocutor, dizendo entre o sério e o brincalhão: "Dê-nos o Padre que está conduzindo consigo". "E Filadélfia?" Perguntou "Filadélfia que se ajuste. Somos filhos de Deus, também nós, como eles temos direito a um sacerdote" respondeu aquela mulher (TONINI, 1996, p.42). 
Nesse diálogo, observa-se que a relação entre alguns sertanejos, a maioria não letrados, e os missionários orionitas não se deu somente no campo da submissão cultural ou hierárquica, dada a posição religiosa dos missionários, além da cultura considerada letrada e europeia dos mesmos.

Houve respeito, consideração e afeto, mas essa gentileza para com os orionitas não significou submissão dos sertanejos diante dos missionários, conforme se pode observar ainda neste diálogo:

Nem havia descido do cavalo, quando aquele homem lhe pediu para visitar um ferido. "Onde está o ferido?" Perguntou o Padre. "Está sobre o banco do açougue, no mercado", respondeu aquele homem. "O que vocês pensam que eu sou, um açougueiro?" Disse o Padre. O homem respondeu: "Desculpe Padre, nós o pusemos lá, porque aqui, como o senhor sabe, não tem cadeia e o mercado serve para tudo". O Padre disse: "Pobre desse povo então, seus feridos aqui são colocados nos açougues". No que o homem disse: "Padre, deixe a política de lado e venha fazer uma obra de caridade, pelo amor de Deus!" (TONINI, 1996, p.93).

Neste diálogo travado entre o sertanejo e Tonini, o sertanejo repreendeu o missionário. Considera-se esse diálogo importante porque demonstra o fato de que a relação entre os sertanejos do extremo norte goiano e os missionários orionitas não se deu de forma submissa. Como dito anteriormente, havia o respeito e a consideração, mas isso não significou submissão de um diante do outro.

Em outro registro de Tonini, percebe-se que não havia submissão entre o sertanejo e os missionários. No caso específico, o sertanejo do lugar se encarregou de espalhar boatos que não agradaram os orionitas, conforme Tonini registrou:

Há uma semana passou por aqui um velho comprador de animais e a todos relatou o que tinha visto e ouvido em uma das casas por onde o senhor passou há dez dias atrás. O povo se apavorou. "Desculpe, mas o que disse o desgraçado?" Perguntou o Padre. O homem respondeu: "Disse que, segundo o seu parecer, o senhor não devia mesmo ser um sacerdote, porque ele, com sessenta anos nas costas, jamais tinha visto um padre tocar música" (TONINI, 1996, p.65).

Percebe-se que os sertanejos hospedaram os orionitas, serviam-lhes de igual forma; mas também, em determinados momentos, os contrariaram. Não significa inferir que a relação entre eles se deu com animosidade, mas essa animosidade também existiu. Os sertanejos ora colaboraram com os orionitas, ora não colaboraram, e como observado no último registro de Tonini, algumas vezes chegaram a dificultar o trabalho dos missionários. 
Nas idas e vindas pelo sertão goiano, Tonini e os missionários orionitas foram bem recebidos pelos sertanejos, conforme ele registrou: "Com a chegada daqueles missionários haveria ajuntamento de muita gente dos arredores. Portanto, jogos, disparos, corrida de cavalos, animava-se aquele povo como uma metrópole se animava para uma olimpíada" (TONINI, 1996, p.126).

Nesse registro do missionário, em que relata o ajuntamento de pessoas que soltavam fogos e promoviam jogos, chama a atenção a imagem de um sertanejo "animado", indo, portanto, ao encontro do que Fadel Davi Filho resume, ao relatar a cultura comum dos sertanejos do interior do Brasil, quando refletiu que "É comum no Brasil denominar o homem do interior de 'sertanejo', caracterizado como uma pessoa simplória e possuidora de uma cultura peculiar" (FILHO, 2011, p.86).

Em contraste com momentos de alegria, havia também a tristeza quando era chegada a hora da despedida de Tonini e dos missionários junto aos sertanejos, como se percebe neste registro:

Aquela era a vida do missionário. Ao subir na cela, notou que alguns enxugavam as próprias lágrimas. A partida do missionário significava para o povo do sertão a volta às suas monótonas e seculares ocupações, no isolamento da floresta. Aquele povo sentia a perda de alguma coisa querida, que talvez por um ano haveriam de encontrar. Para aquele povo, a felicidade era como um relâmpago (TONINI, 1996, p.126).

É possível observar que nos registros de memória de Tonini, ao que parece, existe uma valorização deles próprios como agentes portadores da solução para quase tudo, inclusive para o estado de espírito dos sertanejos. É como se por onde eles passassem tudo mudasse.

Vale observar que Tonini, em seus registros de memória, construiu representações depreciativas dos sertanejos do extremo norte goiano. Representações como: pobres, miseráveis, desvalidos e esquecidos, conforme registrou:

Os velhos goianos sempre diziam: "não deixe a estrada mais longa para seguir a mais curta. A mais longa é sempre a melhor". Mas quem vinha da Itália para ensinar por aquelas bandas, pensava não ter mais nada a aprender com aqueles analfabetos (TONINI, 1996, p.54).

Considera-se que havia uma justificativa para a representação do sertanejo como um povo analfabeto. No caso, a explicação passa pelo interesse dos missionários orionitas em 
justificar suas ações por aquelas regiões na área da educação, no campo religioso, no sentido de formar um estrato social mais educado e condizente com as práticas orionitas.

Acredita-se, também, que a representação do sertanejo como analfabeto pode estar muito além do interesse em justificar a necessidade da implantação de uma educação em moldes religiosos e orionitas para a região. Pode haver um interesse muito maior na construção dessa representação, um interesse que só poderia estar ligado a um sentimento de menosprezo e de desqualificação do outro, do diferente, no caso, o sertanejo.

A cultura do sertanejo, considerada pelos orionitas como "não letrada", não justificaria um discurso de inferioridade. A construção do outro como algo inferior está ainda ligada à necessidade de domesticar culturalmente o outro por intermédio de um processo civilizatório que muitas vezes desqualifica, depois estigmatiza e diferencia, para, a partir daí, colocar em prática um projeto; no caso dos missionários orionitas, um projeto catolicizador e também civilizador.

Sobre essa interpretação, Wilhelm Wachholz reflete que "O grande palco religioso latino-americano se caracterizou por embates, conflitos, contrastes, estigmatizações e diferenciações" (WACHHOLZ, 2010, p.111). A partir de Wachholz, entende-se melhor a estratégia de Tonini em estigmatizar e diferenciar o sertanejo. Como se observou no último registro do missionário, ele estigmatizou os sertanejos como analfabetos. E ainda teve o cuidado de usar a expressão no plural, como se deixasse claro que se referia a todos os sertanejos do extremo norte goiano.

Acredita-se que, para colocar o processo catolicizador orionita em curso na região, era necessário enquadrar e até inferiorizar as práticas de fé dos sertanejos. E isso ocorreu seguramente. Paralelamente à construção da representação do sertanejo como pobre, miserável, desvalido, doente e analfabeto, acrescenta-se a "necessidade", ainda, por parte de Tonini, de desqualificar a fé dos sertanejos.

Em outro momento de seus registros de memória, Tonini compara o cristianismo praticado pelos sertanejos da região com o praticado em outros lugares do mundo, isso para entender a situação vivenciada por eles no "front” da missão em Goiás. Segundo ele:

As missões no centro do Brasil nada têm em comum com aquelas tradicionais do oriente. Lá precisa endereçar a fé ao monoteísmo, aqui, ao invés, precisa renovar e revigorar a fé mesma. Lá é a chegada errada, aqui é o início fraco. Lá precisa pescar com anzol, aqui precisa trocar a água. Portanto, os missionários de Dom Orione se encontravam diante dos mesmos problemas que torturam o mundo ocidental, com o agravante das distâncias enormes, da 
falta de meios, da ausência absoluta de apoio dos leigos, da cultura muito escassa, da instabilidade do caráter (TONINI, 1996, p.72).

Nesse registro sobre a situação das missões cristãs e do próprio cristianismo praticado pelos sertanejos do extremo norte de Goiás e a breve comparação com o cristianismo em outras partes do mundo, o missionário busca entender a situação da prática missionária em diferentes contextos espaciais. Em seu registro, Tonini escreveu que havia diferenças entre as missões praticadas no centro do Brasil e as missões no resto mundo, porque o sujeito, no caso, as pessoas, eram outras.

Interessante observar que ele nomeou cinco fatores que, no caso do extremo norte goiano, acabaram por agravar as dificuldades encontradas por eles no sentido da "depuração" do catolicismo praticado pelos sertanejos: as distâncias, a ausência de recursos, o não apoio dos leigos, a cultura e o caráter das populações. De fato, nesse registro de Tonini, ficam claras as representações dele sobre a região do extremo norte goiano e o que eles julgavam como fatores que dificultavam os trabalhos naquele momento histórico. Era preciso então, segundo Tonini, conquistar para o catolicismo o espaço (sertão) e seus moradores (sertanejos).

Pelo exposto neste estudo, considera-se inferir que os principais personagens com os quais Tonini e os missionários orionitas tiveram de lidar no seu cotidiano foram os sertanejos daquele sertão: o extremo norte goiano. Nesse sentido, como Tonini representou os sertanejos em suas memórias? Os sertanejos foram representados como solidários, como pessoas ativas, autônomas, que gostavam dos missionários, mas por vezes causavam aborrecimentos. Os sertanejos foram representados também como aqueles que por vezes davam conselhos aos missionários, conhecedores que eram do sertão, mas também esses sertanejos foram representados como sujeitos analfabetos e possuidores de uma cultura "inferior".

Portanto, Tonini representou em suas memórias os sertanejos como sujeitos bons, mas também os menosprezou como não letrados e sem cultura. Por que os sertanejos foram representados dessa forma nas memórias de Tonini? Havia um sentido nessa representação? O que ela esconde? Na busca para entendermos essas problemáticas, a partir de Roger Chartier, também se acredita que:

As percepções do social não são de forma alguma discursos neutros: produzem estratégias e práticas (sociais, escolares, políticas) que tendem a impor uma autoridade à custa de outros, por ela menosprezados, a legitimar um projeto reformador ou a justificar, para os próprios indivíduos, as suas escolhas e condutas (CHARTIER, 1982, p.17). 
A partir de Chartier, acredita-se que as representações do missionário Tonini, seus registros de memória, são percepções do social, não são discursos sem sentido; pois, para Chartier, produzem estratégias e práticas sociais e políticas. Considera-se que foi o que ocorreu com a construção das representações por parte do missionário Tonini sobre os sertanejos da região: Tonini e os missionários os menosprezaram em suas representações em nome de uma estratégia, que tinha, como objetivo último, justificar a implantação do projeto orionita para o sertão do antigo extremo norte de Goiás, atualmente denominado norte do Tocantins.

\section{Considerações Finais}

O objetivo deste estudo foi analisar as representações de Quinto Tonini, missionário orionita italiano que viajou pelo sertão do antigo extremo norte de Goiás, na década de 1950. Nesse sertão, Tonini conheceu e conviveu com os sertanejos do Brasil central. Ele registrou as suas viagens, suas experiências e sua convivência com aqueles que ele encontrou: os sertanejos.

Este estudo foi resultado de uma pesquisa bibliográfica, analisou-se o livro de memórias de Tonini, a obra Entre Diamantes e Cristais. Nele, foi possível identificar que as viagens que Tonini realizou se enquadraram naquilo que os estudiosos do tema chamam de desobrigas. Foi possível também, através de outros estudos, diferenciarmos o que é desobriga do que é uma missão evangelizadora. Muito embora Tonini e os orionitas se considerassem missionários, as viagens que eles fizeram pelo sertão do antigo extremo norte goiano foram desobrigas.

Viu-se também que essas desobrigas tiveram como "palco" os sertões do antigo extremo norte goiano. O próprio Tonini chamou a região de sertão. Esse sertão, cravado no coração do Brasil central, foi o lugar privilegiado das viagens de Tonini, considerado o principal missionário orionita na década de 1950 em Goiás. O sertão goiano, como foi possível perceber, foi um lugar marcado por dificuldades e pobreza. Sob o chão desse sertão, registrou-se na memória de Tonini, relatos que fazem parte da história do catolicismo na região na metade da década de 1950.

No sertão do extremo norte goiano, Tonini conviveu com seus sertanejos e os representou em sua memória escrita. Às vezes esse sertanejo foi representado como um hospedeiro afetivo, dócil, educado e cordial. Às vezes, como analfabeto, rústico, miserável e sem cultura. Tonini precisou estigmatizar esses sertanejos para, enfim, justificar a catolicização dos mesmos, ganhá-los para o catolicismo orionita. 
Infere-se que a hipótese antes presumida se encontra confirmada. Por tudo que Tonini escreveu dele mesmo, de suas viagens, do sertão e dos sertanejos, tendo, é claro, ele próprio Tonini - como o personagem principal dessa história, ele terminou por empreender um esforço de memória, para que ele próprio e os orionitas fossem lembrados como os desbravadores do sertão do antigo extremo de Goiás, do ponto de vista do catolicismo.

Ao implementarmos uma metodologia de análise das memórias de Tonini, a partir de estudos de vários pesquisadores, sob a luz de conceitos como desobrigas, sertão e sertanejos, conceitos esses interpretados a partir de estudos no campo da história cultural, considera-se que este estudo justificou a necessidade antes exposta, de historicizar as memórias de Tonini, o que contribui para a compreensão de parte da história religiosa católica do sertão do antigo extremo norte de Goiás, atual Tocantins.

\section{Referências}

AB’SABER, Aziz Nacib. Os Sertões: A Originalidade da Terra. Ciência Hoje, 3 (18): pp.43$52,1985$.

AMADO, Janaína. Região, Sertão, Nação. Revista Estudos Históricos, Rio de Janeiro, VOL.8, N.15. P.145-151, 1995.

CORMINEIRO, Olívia Miranda Macedo. Trilhas, Veredas e Ribeiras: Os Modos de Viver dos Sertanejos Pobres nos Vales dos Rios Araguaia e Tocantins (Séculos XIX e XX). 2010. Dissertação (Mestrado em História) - Programa de Pós Graduação em História, Universidade Federal de Uberlândia.

CHARTIER, Roger. A História Cultural: Entre Práticas e Representações. Lisboa: Difel, 1982.

FERREIRA, Rodrigo de Souza. Os Dançadores do Rosário Ganham Novos Trajes: Congada, Igreja e Amigos da Congada em Brás Pires, MG. Tese (Doutorado em História) - Programa de Pós-Graduação em História, Universidade Federal de Viçosa.

FILHO, Fadel David Antônio. Sobre a Palavra Sertão: Origens, Significados e Usos no Brasil do Ponto de Vista da Ciência Geográfica. Revista Ciência Geográfica, Vol.15, N.1, 2011.

MESQUITA, Peri. Crise do Capitalismo Agrário e Solução Católica no Paraná. Revista Diálogo Educacional, V.1, N.1. P.1-95, 2000.

PATTARELlO, Giovani. Perfil de Dom Orione. São Paulo: S/Editora, 1985.

SANTOS, Edivaldo Antônio dos. Os Dominicanos em Goiás e Tocantins (1881-1930): Fundação e Consolidação da Missão Dominicana no Brasil. 1996. Dissertação (Mestrado em História) - Programa de Pós Graduação em História, Universidade Federal de Goiás. 
Representações em relatos de memória: o Missionário Católico Quinto Tonini no antigo extremo norte de Goiás na década de 1950 - Raylinn Barros da Silva

TONINI, Quinto. Entre Diamantes e Cristais: Cenas Vividas Pelos Missionários de Dom Orione nas Matas do Norte de Goiás. Fortaleza: Expressão, 1996.

WACHHOLZ, Wilhelm. As Religiões e Seus Mecanismos de Exclusão: Um Ensaio. Estudos de Religião, V.24, N.39, 107-121, 2010.

Recebido em: 03/01/2020

Aprovado em: 07/04/2020 